\title{
Original Article \\ Foucault's progeny: Jamie Oliver and the art of governing obesity
}

\author{
Megan Warin \\ Life Course \& Intergenerational Health Research Group, Discipline of Gender, Work and \\ Social Inquiry, Level 5, Ligertwood Building, University of Adelaide, Adelaide 5005, \\ South Australia.
}

\begin{abstract}
Jamie Oliver is an English celebrity chef who has publicly politicised the relationships between class and food in Britain. No longer a simple chef, Oliver is presented as an evangelical saint, salvation of British school dinners, advocate for young disadvantaged kids, and now with his latest series Ministry of Food, a saviour of the British obesity epidemic. In this series, the population of Rotherham is surveilled and targeted as representative of poor eating habits and lifestyles in Britain. In need of urgent intervention, the townsfolk are urged to make themselves anew and 'fight' their way out of the obesity epidemic. Moving beyond a mechanistic application of Foucault, this article examines the intersections of different technologies that give rise to specific lifestyle interventions, and the forms of resistance they generate. Through a convergence of the cultural technology of reality TV and technologies of self-governance, this article argues that a novel form of obesity intervention is being re-invented in a health promoting, neoliberal environment.

Social Theory \& Health (2011) 9, 24-40. doi:10.1057/sth.2010.2;

published online 1 December 2010
\end{abstract}

Keywords: obesity; governmentality; reality TV; technologies; health promotion; resistance

\section{Introduction}

In 2008 Jamie Oliver embarked on his latest television campaign which was screened on Britain's Channel 4 across four, 1-h episodes. In the Ministry of Food, Jamie spent time in Rotherham, a northern industrial town in South Yorkshire. Rotherham is one of the most deprived areas of England, and areas around the town centre have multiple deprivation levels that put them in the worst 6 per cent for the whole country (Rotherham Deprivation Study, 2005). Jamie chose Rotherham in part because of these statistics, but also because this

(C) 2011 Macmillan Publishers Ltd. 1477-8211 Social Theory \& Health Vol. 9, 1, 24-40 www.palgrave-journals.com/sth/ 
is where Julie Critchlow hails, a local woman who had hit international headlines when she and other mothers allegedly passed burgers, chips and crisps to their children through the Rawmarsh comprehensive school fence in 2006, in defiance of new healthy food school dinners that Jamie had been instrumental in rolling out across the United Kingdom.

Oliver famously referred to Julie at the time as a 'big scrubber', and her actions left him wondering why people (and especially mothers) would sabotage a programme that has the potential to improve the health of their kids. In the manifesto which accompanies The Ministry of Food, Oliver states that these 'nagging' issues led him to 'dig into them' and find out what is going on in these people's homes, what they are eating and why 'our diet is helping turn us into one of the most obese countries in the world' (Oliver, 2008, p. 1). In the first episode the cameras follow Jamie as he knocks on Julie's front door to apologise and ask her to support the Pass It On scheme in Rotherham. While always defiant and claiming that Oliver 'lives in a bubble', Julie becomes a central player and ally in the new television series.

This article explores the cultural politics of power and resistance at play here, and in particular the possibilities that give rise to allow a young, wealthy, white man to come to an English northern town and save it from obesity. The Ministry of Food is explicitly about the politics of health, class and place, and is a novel form of what Deleuze (1995), in his reading of Foucault, refers to as 'control societies'. Televised forms of governmentality has been well articulated by Ouellette and Hay (2008), who argue that reality TV has become a new form of cultural technology in which individuals and populations learn how to take care of themselves through self-monitoring, responsibility, choice and empowerment. There is a proliferation of reality shows aimed at targeting unhealthy lifestyles, and specifically obesity: The Biggest Loser, You are what you Eat, Honey, We're Killing the Kids, Fat Camp and Britain's Biggest Babies (and the international versions of each of these shows) are prime examples of this genre.

Everyday life has become a staple for reality TV, in which 'needy' individuals and populations are targeted, and transformed into functioning citizens (Ouellette and Hay, 2008, p. 6). Individuals are required to take responsibility for a range of lurking risks (ibid, p. 7), which can include insecure homes, germs in the house or the dangers of obesity. Reality TV is a milieu for education and intervention rather than a source of representation, and has thus become one of the most important resources for people to manage their 'out of control' lives in world of risks and insecurities (Lee, 2009, p. 76).

As a risky bodily state that is said to be caused by consuming too much energy dense food and lack of exercise (due to high technology consumption and obesogenic environments), obesity is the perfect topic for reality TV. What distinguishes the Ministry of Food from other weight loss reality shows, 
however, is the targeting of individuals and the whole community (and by implication, a whole region and nation of England). Rather than focusing on individual players in a competitive role play, the community approach presents a new form of reality TV that seemingly fits with social models of 'new' public health. Oliver unknowingly becomes Foucault's progeny, slipping easily into his clothes and demonstrating the new and intimate relationship between reality TV, health promotion and governmentality.

Several scholars have already noted that as a body of theory, governmentality is aligned more with Foucault's later work than his earlier focus on technologies of domination (Coveney, 1998). Foucault himself recognised that he had not spent enough time developing how people take on and practice these technologies, what he refers to as technologies of the self. Rather than see governmentality as a discreet concept in Foucault's later life, it cannot be separated from discourse and surveillance, and technologies of domination and power go hand in hand with his later work of networked circuits of deployment. In examining the relationship between Oliver's show and obesity intervention, this article argues that these networks intersect and are deployed as a novel form of health promotion.

The first section of the article describes Oliver's Ministry and how he uses the discourse of obesity as a known problem to rationalise the campaign in Rotherham. Through the use of selective Rotherham cases, Oliver argues for urgent intervention, and the following section traces the techniques and strategies of empowerment used to propel the citizens of Rotherham into healthy cooking regimes of self-discipline and transformation. These regimes are spatially arranged, and cross community spaces (such as workplaces, local civic spaces, football stadia) and the intimate, private spaces of people's homes. The final section puts Jamie Oliver and his campaign in the context of health promotion and neo-liberal governance, arguing that such a campaign persuades people to conduct themselves as rational and ethical actors who can make choices and govern themselves in a bid to free themselves (and perhaps the nation) from obesity. Oliver's rhetorics of choice and freedom are, however, not always persuasive, and the choir of dissenters becomes louder the longer Oliver's cameras roll. In light of this resistance, the conclusion points to the limitations and inherent dangers of positioning reality TV as a health-promoting mechanism.

\section{Knowing What Needs to be Governed}

In the Ministry of Food Oliver and his film crew enter the domestic life of a British town and capture a snapshot of the country's social health (Lawrence, 2008). As Oliver explains in the foreword to his accompanying book to the 
series and the television show, the Ministry of Food is a campaign to 'get the people of Rotherham cooking', to teach them how to cook and 'Pass It On'. Oliver believes that changes in gender roles, working conditions and loss of time has led to generational loss of vital cooking skills and knowledge, and demonstrates this by introducing the viewers to Natasha, a single mother who feeds her two young children chips and donor kebabs on the floor in front of the television each night. She has never cooked a meal from scratch, and her refrigerator is groaning with chocolate bars and sweets. Oliver retreats to his Land Rover in outrage and incredulation: 'Fucking hell ... it's fucking Great Britain. It's 2008. I've been to Soweto and I've seen AIDS orphans eating better than that'.

The name for Oliver's mission comes from the UK government's Ministry of Food that was appointed in the Second World War to assist the nation to manage rations and food shortages. The job of the wartime Ministry was to educate the public about how to live healthily on little so they'd be 'fighting fit'. Food Advice Centres were set up all over Britain in which cooking demonstrations, recipes and advice was handed out on how to best live on available ingredients, and hundreds of women were enlisted to teach cooking skills in workplaces, schools, factories and local shopping precincts. On his Ministry of Food website, Oliver claims that as a result 'the British public had one of the healthiest diets of any time in history' (Ministry of Food, 2008).

Oliver's Ministry of Food draws explicitly on this WWII model. Complete with a manifesto and an armoury of marketing strategies (including The Sun newspaper, accompanying DVDs, a book and a website), his is a social contagion model that uses military metaphors. The message is simple, Oliver arrives to 'wage war' on the ready meal and takeaway culture of Rotherham and encourage people to cook simple and nutritious foods. As his website proclaims, by 'bombarding the population with health and advice', people 'armed with knowledge' can turn to victory in the 'fight against obesity'. Oliver pulls on the patriotic strings of wartime Britain, in which Rotherham citizens must be mobilised and enter the front line for a new assault on junk food (Gibson, 2008).

This explicit use of military metaphors to propel change is already evident in public health and popular discourses on obesity. Obesity is often characterised as a public health 'time bomb', an 'epidemic' in need of 'combat' (cf. Komesaroff and Thomas, 2007, p. 287; Barry et al, 2009). As Monaghan notes in his ethnographic work on men and obesity in the United Kingdom, it was the US Surgeon General Everett Koop who popularised the 'war on obesity' in 1997, which led in 2003 to obesity being referred to as 'the terror within, a threat that is every bit as real to America as weapons of mass destruction' (Monaghan, 2008, p. 1).

It is the rhetorical force of these metaphors that Oliver uses to move and persuade people into action. He is no stranger to the machinations of 
government bureaucracy, having been instrumental in changing the face of what children in Britain eat every day for their school dinners. Oliver's work with the Blair government in enacting these huge social changes across the nutritional landscape of schools has been supported by major capital investment and positive reviews in the British Medical Journal (Spence, 2005). Similarly, the Ministry of Food campaign is explicitly political, and the manifesto and accompanying letter to government ministers outlines how the public can be empowered to make effective short- and long-term changes in their eating habits, and how this needs to be supported by government funding, and individual and community investment. The goal is to slow or reverse the obesity trend, and in doing so, 'radically improve the health prospects and social welfare of the British public, regardless of age and class' (Oliver, 2008). Like reality TV's premise of setting a challenge (to lose weight, to be the last survivor or win the game) in order to transform people, Oliver's show has a challenge to get the people of Rotherham cooking healthy food, and in doing so transform the obesity problem of Britain.

Through the lens of the camera, Oliver provides a window in which the audience observe and judge the everyday lives of the people of Rotherham. Like all reality TV, the Ministry of Food operates as a panopticon, a model of surveillance in which Oliver becomes an omnipresent guard, policing people's everyday lifestyles. But the disciplinary forces of surveillance have stepped outside Bentham's prison, and seep out into a social body, flowing through the networks of the socius (Rose, 1999). There is more than one guard, for the glare of the nation is upon Rotherham - a viewing audience of 4 million in the United Kingdom alone, sit in their lounge rooms and join in as arbiters of people's diets and lifestyles. Rich and Miah argue that contemporary health discourses are no longer confined to medical contexts, but are encountered through insidious bioethical media events, such as Jamie Oliver's School Dinners (Rich and Miah, 2009 , p. 164). Through the technology of reality TV new forms of health and lifestyle education are produced, and viewers are encouraged to enact these guides in the surveillance of their own daily lives.

The first important effect of this scrutiny is to judge the everyday and private lives of people in Rotherham. Viewers are taken firstly into the private spaces of domestic homes, into refrigerators, cupboards and living rooms. We learn in detail about the organisation of consumption and leisure spaces, what is eaten (and not eaten), and where it is eaten. Ouellette and Hay argue that reality TV's capacity to insert guidelines for living into the nooks and crannies of everyday life is a quintessential technology of advanced neo-liberal citizenship (2008, p. 4). This intrusive examination of the minutiae of everyday life is exemplified in the UK show You Are What You Eat (2004-2007), in which the militant expert and presenter Gillian McKeith takes samples of contestants' faeces to show 
them how the internal workings of their bodies are strained by 'obesogenic lifestyles'. Not content with the surveillance of everyday lives, McKeith surveils the interiority of bodies in their most intimate performances. In reality TV private spaces of bodies and lives are no longer private and become public spectacle and entertainment.

A second important effect of Oliver's ministry is guided by a common premise of reality TV, to 'bring less educated, lower income populations up to middle class standards' (Ouellette and Hay, 2008, p. 6). Oliver taps into stereotypical discourses of life in a northern English town, showing viewers the cyclical and intergenerational effects of poverty on the health of people (although this is never acknowledged as a social determinant of ill-health) in which ignorance is actively constructed as a gap in what these people know. An epistemology of ignorance (Tuana, 2006) underscores the presentation of Rotherham townsfolk, who are unable to read recipes, use a stove, mash a potato, know what boiling water looks like, and even feed their own children. This victim blaming approach feeds directly into a well-established discourse in the United Kingdom about the north-south divide, in which northerners are represented as in a constant state of post-industrial degeneration and stuck in impoverishment. This pervasive political discourse was recently reproduced in a controversial report from Policy Exchange (a UK think tank that advises on public policy) which described two nations in England, the prosperous south and depressed and obesogenic north, in which the only hope for northerners to improve their quality of life is to migrate south (Leunig and Swaffield, 2008).

\section{Persuasions of Rhetoric}

For Oliver's show to be successful, there must be a taken for granted reason for intervening in these people's lives. Reality TV is this rationalisation and comes to the fore as an 'object of regulation [and policy] designed to nurture citizenship and civil society, and an instrument for educating, improving, and shaping subjects' (Ouellette and Hay, 2008, p. 14). Reality TV is not mere representation, it acts as a 'cultural technology' that firstly identifies certain bodies as problematic and then acts as a techne in which skills and knowledge are directed towards production. Just as Foucault argues, these disciplinary technologies and regimes are articulated in accordance with norms constituted by expert knowledges and put into play by disciplinary techniques (Foucault, 1980 , p. 106). And these techniques focus on observation, classification, and the production of normality/abnormality around statistical norms, individualising and standardisation. 
Obesity has been constructed as a problem and disease category through biomedical discourse. It is via medical examinations, the inclusion of obesity and its variants in diagnostic manuals, the collection of population statistics through measurements that define individuals and groups of people as normal/ abnormal, that obesity has been 'made' and classified as a disease of the late twentieth and twenty-first century. Obesity (and its variants) is part of the International Classification of Diseases (ICD-10) and has internationally recognised instruments of calculation (for example, BMI, waist circumference, body fat percentage). Obesity has been the established rationale for international groups (the International Obesity Task Force), has dedicated academic journals of study (Obesity, International Journal of Obesity) and major policies and campaigns in place to tackle it (in the United Kingdom, for example, the recent Healthy Weight, Healthy Lives: A Cross-Government Strategy for England (2008) and the Change4Life campaign (2009)). In all, obesity has come to the fore as an epidemic and as a global crisis, and has an industry and authoritative evidence (for example, medical and economic) to support it (Coveney, 2008).

Oliver uses the legitimating evidence of statistics in his manifesto to persuade viewers of the need for economic and medical management of obese people:

Obesity already costs the NHS [National Health Service] more than smoking: $£ 4.2$ billion versus $£ 2.7$ billion. Over 9000 people already die prematurely each year due to health conditions caused by being overweight; cancer, heart disease, stroke and diabetes are the most common ... Experts now say the problem is escalating so quickly that in ten year's time, 75 per cent of people will be overweight or obese. (Oliver, 2008, p. 1)

Oliver builds the urgency by painting a vivid picture of irreversible risk in declaring: 'If nothing is done, obesity and diet-related health problems will have devastating consequences for the National Health Service ... This will be the first generation in which children are predicted to die before their parents' (ibid.). This tactic for creating the worst possible scenario of future obesity risk is a common strategy of public health campaigns. Diprose (2008) suggests that this posturing of risk demonstrates how public health campaigns concerning obesity (and smoking) have been caught in a paradigm of pre-emption, in which potentialities for the future are imagined and feared within the worst hypothesis (Diprose 2008, p. 142). The reality TV series Honey We're Killing the Kids (2006) similarly uses a strategy of predicted futures to scare people into urgent action. The show begins with computer-generated images of the children involved (based on current behaviours), fast-forwarding to produce images of fat, bloated adults (Kendrick 2008, p. 390).

As well as securing an imagined future (however uncertain this may be) statistics are used to enable action in the present. Rose et al argue that population 
statistics and clinical evidence allow us to know that which has to be governed, and we are able to govern in the light of that knowledge (2006, p. 87). This is a central concern of governmentality, for now knowing what has to be governed a series of questions can flow: Why should they be governed? How should they be governed? And as Coveney (2008) argues in his analysis of the government of girth, there are now certain parts of the population that have been targeted as requiring specific interventions ('the poor', and children in particular).

Governmentality targets populations who lie between the poles of state and family, and are known and have a reality of their own. These populations, such as Rotherham which is popularly known as the 'obesity capital of the UK' (Midgley, 2008) have their own life and internal processes that are independent of government, but require the intervention of government (Rose et al, 2006, p. 87). In response to the obesity epidemic, new practices and agencies of governance emerge, and new instruments of government are invented (ibid, p. 88). Governmentality is not situated in any single body or State but in the broader art of governing populations. Governmentality, Foucault argued, is not concerned with sovereign power, as this is 'too large, too abstract and too rigid', nor located in the 'thin, weak and insubstantial' model of the family (Foucault, 1979a). Rather than a top down model of power in which the state is wholly responsible, he argues that a whole variety of authorities govern in different sites. This involves capillary networks of power: '.. an assemblage of networks, authorities, groups, individuals, and institutions [are] enlisted, brought to identify their own desires and aspirations with those of others' (Miller and Rose, 1990).

Through the Ministry of Food, Oliver produces a storyline of obesity that combines key elements of reality TV and governance. Symbolic references that accompany obesity (and are commonly understood and shared) include a host of moral assumptions (for example, slovenly, uneducated and lazy) that lay the foundation for inordinate future risks to society. It is these behavioural attributes that are the rationalisation of reality TV and in need of transformation. As Nerlich similarly suggests in her analysis of the catastrophic discourses of microbiology, certain points of storylines are selected to make them more salient in a communicating text, in such a way as to promote problem definition, causal interpretation, moral evaluation and/or treatment recommendation (Entman, 1993, p. 53, cited in Nerlich, 2009, p. 576-577). Rotherham is chosen as the media landscape for reality TV's visual performance of this storyline.

\section{Empowering the Citizens of Rotherham through Self-discipline}

Pass It On is the main strategy of Oliver's Ministry of Food, mobilised in order to resurrect and keep cooking skills alive in Rotherham. It is a pyramid scheme 
where eight people are taught one or two dishes that they can then teach two 'mates' who Pass It On again, with the aim of teaching all Rotherham residents (just over 250000) the skills of cooking in a short time frame. To arm people with the knowledge, confidence and tools to learn basic cooking skills, Oliver enlists apprentices. As well as Critchlow, the 'Burger mum', other handpicked helpers are Natasha the single mum, who featured in the first episode; Claire, who admits to a dinner being 10 bags of crisps; and Mick the miner who has 'never even made beans on toast' and thinks cooking is for 'poofs'. Initially, Oliver teaches people to cook in their own homes or environments, trying a recipe, which they can 'master' and pass on. These helpers then spill over into a network or 'army' of helpers, including mothers, fathers, children, schools, workers, local councils and companies.

In taking The Ministry of Food into Rotherham, Oliver is working with ordinary people in their everyday lives, workplaces and domestic homes. Ordinary people are central to reality TV, as reality TV is concerned with 'programs that film real people as they live out events in their lives, contrived or otherwise as they occur' (Nabi et al, 2003, p. 304). Oliver's genre of reality TV is marked by ordinary people like Critchlow who are engaged in unscripted action and interaction and become celebrities in their own right (Nabi, 2007, p. 373), as opposed to celebrities becoming ordinary people (for example, The Osbournes, The Anna Nicole Show). It is people like Critchlow who become points of identification and illustrate that anyone can participate in technologies of self-help and self-actualisation.

Consistent with the viral contagion model, Oliver takes the Pass It On scheme out of domestic kitchens and into the community. This has meant that a number of community spaces have become key sites in the assemblage of authorities, groups and individuals enlisted, all becoming allies in governing. The linchpin of these networks is the centrally located, nongovernment food centre, harking back to the wartime food advisory centres. The walk-in facility, which offers basic cooking courses to the local community, is open from 9:30 to 20:00, 6 days a week and is partly funded by the local authority and Oliver himself. Rotherham citizens can watch professionals cook a meal from scratch and then get hands-on experience themselves. As well as the cooking classes, anyone can drop-in and learn how to cook 'budget friendly and simple food' from the set of 10 meals. In his manifesto Oliver argues that once people learn how to master simple skills of chopping, frying, roasting and baking they'll be able to transfer their skills to home environments, and to other dishes and ingredients.

The relationship between the trainer and the learner is fundamental to Oliver's scheme and to Foucault's concept of governmentality. Governmentality is not simply the government and surveillance of others; it also means the 
government and surveillance of oneself - what Foucault refers to as technologies of the self. In Bentham's panopticon, the prisoner's adjust their behaviours because they know they are constantly being surveilled by unseen guards. In the Ministry of Food the goal is similarly for individuals to know and act upon themselves, in order to make better food choices. Natasha, Claire and Mick learn from Oliver and then become the trainers in Pass It On, using their selfdiscipline to teach and train in a variety of Rotherham locations (in the streets, at the local council, in workplaces and schools). Claire goes to the Rotherham Borough Council to convince the councillors (with a cooking demonstration in which they join in) to fund Pass It On once Oliver has left. Oliver is proud of his apprentices, and in line with Foucault's technologies of self they now conduct their lives as an enterprise, and have become entrepreneurs themselves.

Governmentality thus engages a certain freedom in which the apprentices and converts to Pass It On take on an ethics of responsibility and accountability. In this way technologies of self are formed alongside technologies of domination so that the people of Rotherham produce the ends of government by fulfilling themselves rather than being merely obedient (Rose, 1989). In governing themselves, Foucault's productive forces of power are realised in which agency and choice is created (as opposed to the negative or repressive forces of power put forward by Marxist scholars).

As someone who presents himself as a 'mockney' (someone with a middleclass upbringing who develops a Cockney accent to gain broad popularity and credibility) and self-made celebrity, Oliver follows Foucault's forms of governance in which the 'rules of law, the techniques of management, and also the ethics, the ethos, the practice of self, [are] played with a minimum of domination' (Foucault, 1991). In the Ministry of Food and under the gaze of a national audience, Oliver works to provide the townsfolk with an ethos of agency, self-responsibility and the obligation to maximise one's life. These guiding principles also intersect with 'new public health' principles of participation, enablement and empowerment (Raphael and Bryant, 2002, p. 196) and neoliberal governance.

\section{An Analytics of Resistance under Neoliberal Governance}

Foucault's ideas of self and governmentality are part and parcel of a neoliberal shift in the conduct of modern, moral citizens. Neoliberalism came about from a shift in the welfare state, and operates on the principles of individualism, free markets via deregulation, and decentralisation. Health-care reform has embraced neoliberalism in policy and practice, and its effects are seen in 'privatisation of services, new systems of accountability and cost-effectiveness, and 
efforts to make individuals and communities more reliant and self-determining' (Petersen, 2003, p. 193; Warin et al, 2008). Within this model citizens are now asked to be active health consumers (rather than the previous passive patient) and take responsibility for their own health care. In taking on Oliver's Ministry of Food and ensuring that their food choices are informed, the people of Rotherham are choosing to improve their health and lower the risks associated with overweight and obesity, and are thus modelling good, ethical citizenship. Here the notion of freedom and choice is paramount, as it reflects the active participation of people in self-governance, and keeping the state at bay.

This form of citizenship is embedded in policies of self-responsibility or mutual obligation, to which marginalised and disadvantaged populations are frequently bound. Entitlement to government protected standards of health is increasingly being circumscribed by an obligation in which health-care consumers must be seen to be active in specific duties of health promotion. The state is no longer obligated, and the self becomes entangled in a contract of self-scrutiny and discipline. The No Excuses, No Nannying speech from the UK shadow health secretary in 2008 supports the neoliberal imperative for obese people to act responsibly and change their lifestyles. The conservatives argue that there is no excuse for being obese, and blaming biology or the environment 'for their own shortcomings' lets obese people off the hook. Within a policy of responsibility, businesses, local authorities and 'poor, obese and lazy' people must 'work together' and 'choose healthy living' (Summers, 2008). Similarly, the UK white paper on the nation's health is entitled: Choosing health: Making healthy choices easier, reflecting the neoliberal political climate of individual empowerment, freedom and self-care. In this context, Oliver and his Ministry fulfils the role of social reformer, thus enabling the state to divest itself of many of its obligations.

Of course not everyone is obliged or willing to conduct themselves through a form of good citizenship defined by neoliberal governance, and this is why Julie Critchlow came to such media prominence. Petersen argues that those who seek not to chose self-governance and 'operate outside predetermined lines of action risk being labeled irresponsible or as troublemakers’ (Petersen, 2003, p. 195). This is precisely how Critchlow was represented by Jamie Oliver and the media, and why she achieved international media fame. She and her fellow 'sinner ladies' (as a pun on 'dinner ladies') became known as 'junk food pushers'. Hattersley (2006), writing in The Sunday Times, described photographs of the women feeding their children (which were emblazoned around the world) as like a scene from the satirical comedy Little Britain, in which Critchlow was branded the 'worst mum in Britain' (ibid.).

Ironically, Critchlow said she was responding to outrage from local parents about their children being banned from leaving school premises during lunch

(C) 2011 Macmillan Publishers Ltd. 1477-8211 Social Theory \& Health Vol. 9, 1, 24-40 
times and denied the right to choose what they want to have for lunch. 'Next they'll be going through our cupboards telling us what we can feed them at home' says one mother, 'but we know how to give our children a proper meal better than any school' (Hattersley, 2006). Following the school dinner fiasco resistance groups were formed in opposition to Oliver's crusade (such as 'Mothers against Oliver' which included Critchlow) - and during the Ministry of Food the Jamie go Home blog (http://jamiegohome.com/) ran a scathing running commentary of Oliver's campaign as it rolled in and out of Rotherham. It documented all the gaps that the editors and producers left out of the aired series, such as when in Episode 2 Oliver visited the Rotherham United football club's last game of the season to tell them about Pass It On. Five thousand fans chanted 'you fat bastard' and 'who ate all the pies', throwing his evangelical ministry straight back at him. Oliver hadn't realised that Rotherham people have a fierce history of resistance to outsiders; Cortonwood pit (just outside Rotherham) is where the UK miners strike began in 1984.

In my mind, Critchlow is the most important player in the Ministry of Food series. Her rejection of the ideals of self-discipline and governance demonstrate that people don't simply fall into line, and that possibilities for resistance are embedded in the multiplicity and dynamism of force relations that constitute power. Rather than view Critchlow's actions as a negative reactive to oppressive power (which resonates with narrow and dualist interpretations of Foucault's approach to resistance), Critchlow responds to the identity of 'failed mother' that neo-liberal governance entails her in. She rejects the subject position of an inept mother who cannot feed her own children. She contests Oliver's expert positioning and tries to reinstate her own autonomy, freedom and identity as a mother: 'We know what food the kids like', says Julie 'and it's not polenta' (Hattersley, 2006). Julie's resistance is thus not a negation of power or a tactical reversal, but a generative 'counter power' (Foucault 1979b, pp. 218-220) in which she challenges and subvert dominant discourses, and in doing so, attempts to form herself in new ways.

In her own tactics of resistance against the 'government of individualization' (Foucault 1982, p. 781), Critchlow is also voicing the nuanced details of people’s lives: 'Life isn't simple ... it's always a compromise' (Hattersley, 2006). Julie is always the sceptical bystander; 'they won't buy this' she repeatedly tells Jamie in the show, and she firmly believes that Oliver has no idea about the day-to-day lives of Rotherham people, who carry in their bodies a history of industrialisation, pride and disadvantage. Although Oliver has an admirable mission to teach adults to cook, who can then teach these skills to children, there are a host of structural determinants, such as class, gender and place, that his focus on 'individual skills' overlooks. And this is Julie's criticism, he doesn't understand the constraints under which people live, and that people don't often have choices. 
This is Oliver's blind spot, his inattention to the history, poverty and class positioning of these people. In comparing their eating habits with children in the so-called developing world, he eschews class as a mitigating factor. Obesity, however, has been repeatedly identified as more common in lower socioeconomic groups (Wardle et al, 2002, 2006). There is a large body of literature that identifies links between place, socio-economic status and health inequalities (and is now a key policy objective of the UK government, as evidenced by the 1980 Black report, the Acheson Independent Enquiry into Inequalities in Health 1998). The concept of class, however, is a muted concept in Britain and has been almost removed from political discourse. In Thatcherite and Blairite Britain, class was instead framed as choice. The libertarian Lord Mayor of London, Boris Johnson, was the only person to speak out publicly in Julie Critchlow's defence. Rather than mention class, Johnson argued that 'the poor and the ignorant should be as free to spend their money as they choose as anybody else' (Orr, 2008). In appealing to the neoliberal rhetoric of personal responsibility, 'choice' absolves the State of responsibility and places social problems squarely at people's feet.

\section{Conclusion}

This article is not concerned with whether Oliver's Ministry failed or succeeded in Rotherham. It is, however, concerned with how Oliver came to Rotherham, and proceeded to try and engage the entire population in social change. As in critiques of early health promotion policing or preaching, there is considerable slippage between Oliver's religious and governing ministry. Oliver was labelled in the Jamie Go Home blog as a 'messiah', and his apprentices as 'apostles'. Mick the miner 'had an Epiphany' after making a dish that men really could cook. After their outrage at the limited and selective way in which Oliver represented Rotherham to the world, some locals wanted to 'nail him to a cross'. And the author of the Jamie Go Home blog cynically commented: 'Thank goodness a missionary came to show us posh ham and asparagus' (http://jamiegohome .com/). Foucault would appreciate this analogy, as he believed that both medical and religious regimes are aesthetic disciplines focused on the government of the body.

But Oliver has not operated in this simplistic, top down way. He has not come to Rotherham simply to educate the people in what he thinks is best for them. He has moved beyond a governance of domination and attempted to provide people with their own will for change, and empower the people of Rotherham in their own self-governance. As Rose argues, 'Increasingly, [this] notion of empowerment ... has come to play a crucial role as techniques and technologies of

(C) 2011 Macmillan Publishers Ltd. 1477-8211 Social Theory \& Health Vol. 9, 1, 24-40 
governance, in shaping the conduct of individuals in ways which make them more self-governing' (Rose, 1996). This new form of governing works to create compliant, model citizens, and those who do not take up rules of conduct and specific practices are vilified as being incapable and unable to care for themselves or for others. It is possible that Critchlow presents an opportunity to chip away at and weaken the micro-politics of power, to fashion a new form of subjectivity that Foucault describes in his later work on resistance as self-formation (Foucault, 1982; cf. Thompson, 2003). But her actions, which work within and through the techniques of governance already in place, are represented as evidence of her failed status as a mother. Thus her resistance to neoliberal forces of power are thwarted as they 'reinstate its conditions in the very moment of subversion' (Mills, 2003, p. 261). This is not to argue that Critchlow is trapped in a model of governance, rather to recognise that she appropriates the power and freedom that constitute governance, and operationalises these forces as resistance. In refusing a particular constitution of subjectivity imposed through governance, she destabilises and deregulates the forces that position her.

Asthana and Halliday (2006) argue that despite the policy rhetoric and apparent understanding of the need for a comprehensive range of social policies in tackling health inequalities, the UK government's health inequalities strategy remains highly behavioural and individualistic (2006, p. 562). This confusion between a wider social model of health and a narrow intervention has come hand in hand with neoliberal environments that focus not so much on equality, but on concepts of opportunity and responsibility. In this shift, large-scale bureaucracies are not seen as the most appropriate way to manage people, so links between State and private entities are relied upon to navigate individual responsibility and change (ibid, p. 585). Reality TV is an opportunity for governing at a distance in which guidelines and regimes for care of self are presented as rational and practical means to become an ethical health consumer and citizen.

Couldry (2008) suggests that reality TV is the secret theatre of neo-liberalism, in which common sense is naturalised, validated and performed on screen. In response to Jamie's first reality TV show on school dinners, Scottish GP Spence stated in the British Medical Journal: 'Jamie Oliver has done more for the public health of our children than a corduroy army of health promotion workers or a $£ 100 \mathrm{~m}$ Saatchi \& Saatchi campaign' (2005, p. 678). Such validation unreflexively accepts the rhetorical storyline of obesity and ignores the contextualisation of people's lives. It is to people like Julie Critchlow and other Rotherham dissenters, that we have the most to learn about the ways in which food and weight is deeply enmeshed in the socio-economic and gendered relations of people's lives (often across generations) and cannot be changed overnight (or in four episodes). 


\section{Acknowledgement}

I acknowledge Professor John Coveney and the engagement of postgraduate students at Durham University, UK (Advanced Theory in Medical Anthropology) for their input into the formulation of these ideas.

\section{About the Author}

Megan Warin is a social anthropologist whose teaching and research interests coalesce around the gendering of health and illness, the embodiment of food and memory, and theory in medical anthropology. Warin has worked in Australian and UK universities, and is a member of the Life Course and Intergenerational Health Research Group, where she is exploring gender and class differences in obesity in an Australian context. She is also examining Persian women's experiences of memory and migration, with anthropology colleagues at the Australian National University.

\section{References}

Asthana, S. and Halliday, J. (2006) What Works in Tackling Health Inequalities?: Pathways, Policies and Practice through the Lifecourse. Bristol, UK: The Policy Press.

Barry, C., Brescoll, V., Brownell, K. and Schlesinger, M. (2009) Obesity metaphors: How beliefs about the causes of obesity affect support for public policy. Milbank Quarterly 87(1): 7-47.

Change4Life (2009) http://www.nhs.uk/change4life/Pages/Default.

Couldry, N. (2008) Reality TV, or the secret theatre of neoliberalism. The Review of Education, Pedagogy and Cultural Studies 30: 3-13.

Coveney, J. (1998) The government and ethics of health promotion: The importance of Foucault. Health Education Research 13(3): 459-468.

Coveney, J. (2008) The government of girth. Health Sociology Review 17(2): 199-213.

Deleuze, G. (1995) Control and becoming. translated by M. Joughin Negotiations. New York: Columbia University Press, pp. 169-176.

Diprose, R. (2008) Biopolitical technologies of prevention. Health Sociology Review 17(2): 141-150.

Entman, R. (1993) Framing: Towards clarification of a fractured paradigm. Journal of Communication 43: 51-58.

Foucault, M. (1979a) Governmentality. Ideology and Consciousness 6: 5-22.

Foucault, M. (1979b) Discipline and Punish: The Birth of the Prison. New York: Vintage Books.

Foucault, M. (1980) Power/Knowledge: Selected Interviews and Other Writings, 1972-1977. London: Harvester Press.

Foucault, M. (1982) The subject and power. Critical Inquiry 8(4): 777-795.

Foucault, M. (1991) Governmentality. In: G. Burchell, C. Gordon and P. Miller (eds.) The Foucault Effect: Studies in Governmentality. Chicago, IL: University of Chicago, pp. 87-104.

Gibson, O. (2008) Now Jamie Oliver wants Britain on a wartime diet. The Guardian 29 March. 
Hattersley, G. (2006) We know what food the kids like, and it's not Polenta. The Sunday Times 24 September.

Jamie Go Home Blog. (2008) http://jamiegohome.com/, accessed March 2009.

Kendrick, R. (2008) We can change the face of this future': Television transforming the fat child. Australian Feminist Studies 23(57): 389-400.

Komesaroff, P. and Thomas, S. (2007) Combating the obesity epidemic: Cultural problems demand cultural solutions. Internal Medicine Journal 37(5): 287-289.

Lawrence, F. (2008) Britain on a plate. The Guardian 1 October.

Lee, H. (2009) Book review: Ouellette, L., \& Hay, J. (2008). Better living through reality TV. Journal of Communication Inquiry 33: 75-82.

Leunig, T. and Swaffield, J. (2008) Cities Unlimited: Making Urban Regeneration Work. London: Policy Exchange.

Midgley, C. (2008) Jamie tucks into the poor and fat: TV's staple diet. Times Online, 9 October.

Miller, P. and Rose, N. (1990) Governing economic life. Economy and Society 19(1): 1-31.

Mills, C. (2003) Contesting the political: Butler and Foucault on power and resistance. The Journal of Political Philosophy 3: 253-272.

Ministry of Food. (2008) About Jamie’s ministry of food, http://www.jamiesministryoffood.com/ content/jo/about.html, accessed 9 March 2009.

Monaghan, L. (2008) Men and the War on Obesity: A Sociological Study. London: Routledge.

Nabi, R. (2007) Determining dimensions of reality: A concept mapping of the reality TV landscape. Journal of Broadcasting and Electronic Media 51(2): 371-390.

Nabi, R., Biely, E., Morgan, S. and Stitt, C. (2003) Reality-based television programming and the psychology of its appeal. Media Psychology, 1532-785X, 5(4): 303-330.

Nerlich, B. (2009) The post-antibiotic apocalypse and the war on superbugs: Catastrophe discourse in microbiology, its rhetorical form and political function. Public Understanding of Science 18(5): 574-590.

Oliver, J. (2008) Ministry of food, Jamie's manifesto, http://www.jamieoliver.com/jamies-ministryof-food, accessed 9 March 2009.

Ouellette, L. and Hay, J. (2008) Better Living Through Reality TV: Television and Post-Welfare Citizenship. Oxford, UK: Blackwell Publishing.

Orr, D. (2008) Should we tell people what to eat? The Independent 4 October.

Petersen, A. (2003) Governmentality, critical scholarship and medical humanities. Journal of Medical Humanities 24(3/4): 187-201.

Raphael, D. and Bryant, T. (2002) The limitations of population health as a model for a new public health. Health Promotion International 17(2): 189-199.

Rich, E. and Miah, A. (2009) Prosthetic surveillance: The medical governance of healthy bodies in cyberspace. Surveillance \& Society 6(2): 163-177.

Rose, N. (1989) Governing the Soul: The Shaping of the Private Self. London: Routledge.

Rose, N. (1996) The death of the social? Re-figuring the territory of government. Economy and Society 25(3): 327-356.

Rose, N. (1999) Powers of Freedom: Reframing Political Thought. Cambridge: Cambridge University Press.

Rose, N., O’Malley, P. and Valverde, M. (2006) Governmentality. Annual Review of Law Society 2: $83-104$.

Rotherham Deprivation Study. (2005) http://www.rotherham.gov.uk/graphics/YourCouncil/Policy + Research + and + Community + Engagement/_Deprivation + Study.htm, accessed March 2009.

Spence, D. (2005) Jamie's school dinners. British Medical Journal 330: 678.

Summers, D. (2008) No excuses for being fat, tories insist as they launch new deal on public health. The Guardian 27 August.

Thompson, K. (2003) Forms of resistance: Foucault on tactical reversal and self-formation. Continental Philosophy Review 36: 113-138. 
Tuana, N. (2006) The speculum of ignorance: The women's health movement and epistemologies of ignorance. Hypatia 21(3): 1-19.

Wardle, J., Brodersen, N., Cole, T., Jarvis, M. and Boniface, D. (2006) Development of adiposity in adolescence: Five year longitudinal study of an ethnically and socio-economically diverse sample of young people in Britain. British Medical Journal 332: 1130-1135.

Wardle, J., Waller, J. and Jarvis, M. (2002) Sex differences in the association of socioeconomic status with obesity. American Journal of Public Health 92: 1299-1304.

Warin, M., Turner, K., Moore, V. and Davies, M. (2008) Consuming bodies: Mall walking and the possibilities of consumption. Health Sociology Review, (special edition) 17(2): 187-198. 